\title{
Alfalfa Mosaic Virus Movement Protein Induces Tubules in Plant Protoplasts
}

\author{
Huanquan Zheng, Guiling Wang, and Lee Zhang \\ The Laboratory of Plant Virology and Biotechnology, Institute of Molecular Agrobiology, 59A, The Fleming, \\ 1 Singapore Science Park Drive, Singapore 118240 \\ Accepted 14 July 1997.
}

\begin{abstract}
The alfalfa mosaic virus (AIMV) movement protein (MP) was fused with the green fluorescence protein (GFP). The MP-GFP fusion was transiently expressed in protoplasts prepared from Nicotiana tabacum, resulting in the production of long, extending, tubular structures protruding from the protoplast surface. Deletions of MP amino acids 1 to 77,84 to 142 , or 226 to 300 all affected tubule formation. Hence, the AIMV MP is solely required for the induction of the tubular structures, and the results suggest that AIMV may move from cell to cell via tubules.
\end{abstract}

Plant viruses need to spread from cell to cell in order to establish systemic infections in plant. The cell-to-cell movement of plant viruses presumably occurs through plasmodesmata, the channels that cross plant cell walls (Ding et al. 1992; Lucas and Gilbertson 1994). It has been shown that many plant viruses encode at least one specific movement protein (MP) to mediate plant virus spread from cell to cell (for reviews see Atabekov and Taliansky 1990; Robards and Lucas 1990; Hull 1991; Maule 1991; Deom et al. 1992). The movement proteins (MPs) of many plant viruses share some conserved motifs (Melcher 1990; Koonin et al. 1991; Mushegian and Koonin 1993).

There are at least two general hypothetical pathways for the cell-to-cell movement of plant viruses. One of them is exemplified by the cell-to-cell movement of tobacco mosaic virus (TMV). TMV moves from cell to cell by forming an MP-viral RNA complex (Citovsky et al. 1990, 1992), presumably trafficking to the cell wall and passing through it via plasmodesmata that have been modified by the TMV MP (Wolf et al. 1989; Waigmann et al. 1994; Heinlein et al. 1995; McLean et al. 1995). The other pathway for plant virus cell-to-cell movement is represented by cowpea mosaic virus (CPMV). CPMV moves from cell to cell by forming tubular structures that contain virus particles. These tubules protrude through the cell wall into the other cells to transport the virus (van Lent et al. 1990; Wellink and van Kammen 1989; Wellink et al. 1993). Similarly, cauliflower mosaic virus, tomato spotted wilt virus, grapevine fanleaf nepovirus, and Euphorbia mosaic geminivirus all produce polar tubular structures in the virusinfected plants (Storms et al. 1995; Perbal et al. 1993;

Corresponding author: Lee Zhang; E-mail: imazl@leonis.nus.sg
Ritzenthaler et al. 1995; Kim and Lee 1992). The tubuleinducing MPs of the above viruses are believed to share highly conserved structures for tubule formation (Thomas and Maule 1995). Squash leaf curl geminivirus BL1 has been demonstrated to induce endoplasmic reticulum (ER)-derived plant tissue/cell type-specific tubules that extend into the cytoplasm on either side (Ward et al. 1997).

Alfalfa mosaic virus (AlMV) has a genome consisting of three, single-stranded, positive-sense RNAs (Fig. 1A). RNAs 1 and 2 encode proteins (P1 and P2) involved in virus replication (Nassuth and Bol 1983). RNA 3 encodes the coat protein (CP) and a $32-\mathrm{kDa}$ MP that is responsible for the virus cell-tocell movement (Stussi-Garaud et al. 1987; Dore et al. 1991; van der Kuyl et al. 1991; van der Vossen et al. 1995). AlMV MP shares many features with other plant virus MPs. For example, it binds to viral RNAs cooperatively (Schoumacher et al. 1992a, 1992b, 1994); it is associated with the plant cell wall in the vicinity of plasmodesmata (Godefroy-Colburn et al. 1986; Stussi-Garaud et al. 1987; Erny et al. 1992); and it is capable of increasing plasmodesmal permeability (Poirson et al. 1993).

Despite intensive studies on the characterization of the MP functions in virus infection, it is still uncertain how AlMV undergoes intercellular movement, which is postulated to be mediated by the MP, and how the MP is transported to the vicinity of plasmodesmata where it functions. To test if the AlMV MP also induces tubules, we fused the AlMV MP coding sequences with the $\mathrm{N}$ terminus of the green fluorescence protein (GFP) coding sequences. The GFP from jellyfish Aequorea victoria is a 238 amino acid protein (Chalfie et al. 1994) and it has been used as a convenient protein expression marker in many heterologous systems (Sheen et al. 1995), including in the studies of plant virus MPs (McLean et al. 1995; Heinlein et al. 1995). The results from the viral protein-GFP fusion studies suggest that the functions of the viral proteins are unaffected by the fusion (Oparka et al. 1996). The expression of plant virus MP in plant protoplast has been successfully used for characterization of MPs of other plant viruses (Wellink et al. 1993; Storms et al. 1995; McLean et al. 1995; Heinlein et al. 1995; Kasteel et al. 1996). To study AlMV MP produced from a transient expression system, we generated two plant expression vectors, pE6113-GFP (Fig. 1B) and pE6113-MPGFP (Fig. 1C). The control vector pE6113-GFP was made by replacing the $\beta$-glucuronidase 
(GUS) gene in the vector pE6113-GUS with GFP gene excised from the vector pGFP2. The plasmid vector pGFP2 containing a mutated GFP gene described previously (Haseloff and Amos 1995) was a gift from Nam-Hai Chua (Rockefeller University, New York) and the plasmid vector pE6113-GUS containing an enhanced 35S promoter and a $5^{\prime}$ untranslated region $(\Omega)$ of TMV SPS strain (Mitsuhara et al. 1996) was kindly provided by Masashi Ugaki (National Institute of Agrobiological Resources, Ibaraki, Japan). The MPGFP fusion vector pE6113-MPGFP was produced by inserting the AlMV MP gene into pE6113-GFP to fuse the MP coding sequences with the $\mathrm{N}$ terminus of GFP sequences. The gene encoding for the MP of AlMV was amplified by the $p f u$ DNA polymerase (Stratagene, La Jolla, CA) mediated polymerase chain reaction (PCR). The RNA-3 cDNA clone of AlMV-CA strain (the procedure for cloning cDNA of AlMV-CA RNAs will be published elsewhere) was used as the template. The primers MP5 (5'CGTCTAGACCATGGAGAATACAAAAA CAAATGCC 3') and MP3 (5'GGGGTACCATGATCGGGTA ATATTTCATCTTT 3') were used as $5^{\prime}$ end and $3^{\prime}$ end primers, respectively, for the PCR reaction. The primer MP5 con-

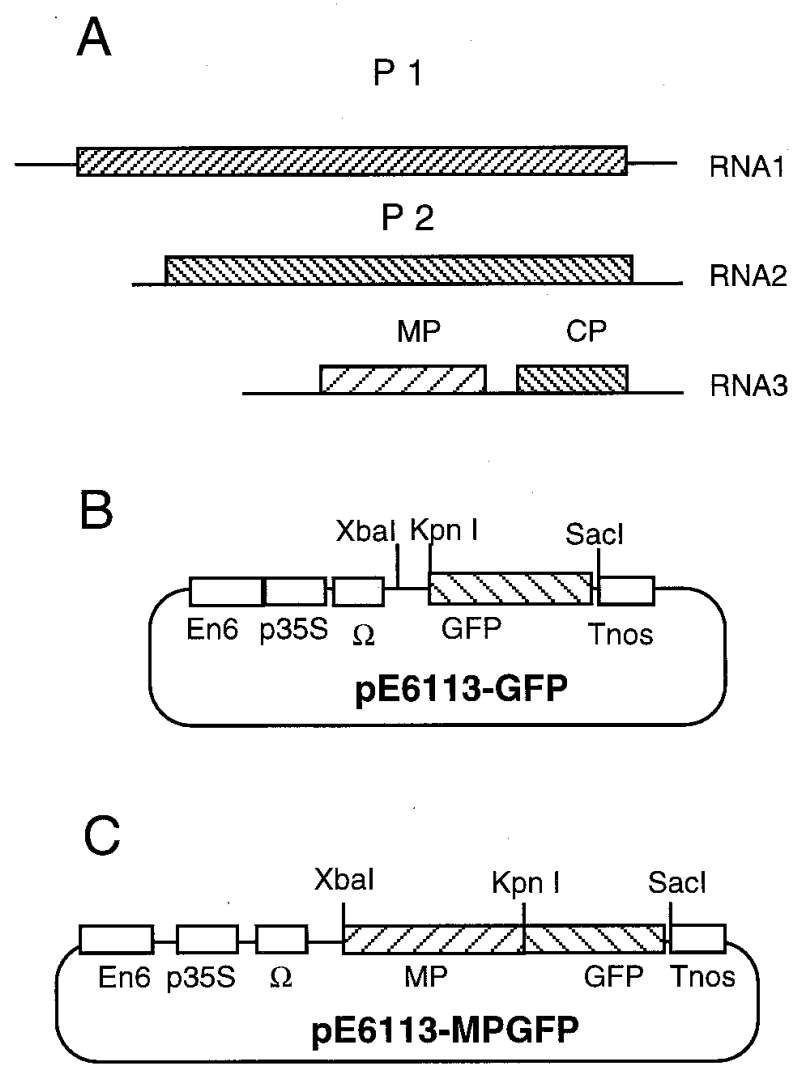

Fig. 1. Schematic representations of the alfalfa mosaic virus (AlMV) genome and the constructs of the movement protein-green fluorescence protein (MP-GFP) fusion protein. A, The AlMV genome: RNA-1, RNA2, and RNA-3. The MP and the coat protein $(\mathrm{CP})$ are encoded by RNA 3 . The gene encoding the GFP was expressed from a plasmid, either (B) as free GFP from pE6113-GFP, or (C) fused to the AlMV MP gene. 35S: cauliflower mosaic virus $35 \mathrm{~S}$ promoter; En6: 5' upstream sequences of $35 \mathrm{~S}$ promoter $(-940$ to -390$)$ and 6 repeats of the sequences from -390 to $-90 ; \Omega$ : $5^{\prime}$ untranslated region of tobacco mosaic virus SPS strain; GUS: the $\beta$-glucuronidase gene; Tnos: the polyadenylation signal of nopaline synthase; GFP: green fluorescence protein gene. tains an $X b a \mathrm{I}$ site (underlined) followed by the 26 nucleotides that correspond to the $5^{\prime}$ end of the AlMV MP coding sequences. The primer MP3 contains a KpnI site (underlined) followed by 24 nucleotides that are complementary to the $3^{\prime}$ end of the AlMV MP coding sequences. The amplified MP gene was digested with $X b a \mathrm{I}$ and KpnI and the excised MP gene fragment was ligated into pE6113-GFP, which was linearized with $\mathrm{Xba \textrm {I }}$ and $K p n \mathrm{I}$. The sequences of the recombinant vectors, pE6113-GFP and pE6113-MPGFP, were confirmed by automatic sequencing on an ABI PRISM 377 DNA sequencer (Perkin Elmer, Foster City, CA) with the ABI PRISM Dye Terminator Cycle Sequencing Ready Reaction Kit (Perkin Elmer).

After generating the fusion construct between the AlMV MP gene and the GFP gene, we transiently expressed the AlMV MP-GFP fusion in the protoplasts prepared from Nicotiana tabacum Bright Yellow-2 (BY-2) suspension cells. The BY-2 suspension cells were maintained as described by Banjoko and Trelease (1995). The suspension cells were subcultured every 7 days.

For transient expression of AlMV MP, the suspension cells were harvested by centrifugation at $140 \times g$ for $5 \mathrm{~min}$ and then washed once with MM buffer (0.4 M mannitol, $20 \mathrm{mM} 2-(\mathrm{N}$ morpholino)ethanesulfonic acid [MES] $\mathrm{pH}$ 5.8). The washed cells were resuspended in MM buffer containing $1 \%$ cellulase "Onozuka" RS (Yakult Honsha, Tokyo) and $0.1 \%$ pectolyase (Sigma, St. Louis, MO), and incubated for $2 \mathrm{~h}$ at room temperature with gentle agitation for the cell wall digestion.

Transfection of BY-2 protoplasts with pE6113-GFP and pE6113-MPGFP was performed by a polyethylene glycolmediated DNA transfection procedure described previously (Morgan and Ow 1995). The transfected protoplasts were examined on the inverted epifluorescence microscope (Olympus IX70, Tokyo) with the following filters: excitation filter 450 to $480 \mathrm{~nm}$, dichroic mirror $500 \mathrm{~nm}$, and emission filter $515 \mathrm{~nm}$. Photographs were taken with the PM-30 automatic photomicrographic system (Olympus) and Kodak Ektachrome 400X film.

The transfected protoplast samples were observed every $2 \mathrm{~h}$ post transfection to examine the kinetics of tubule formation. A punctate distribution of the MP-GFP at the locale of plasma membranes was observed as the initial event $2 \mathrm{~h}$ after transfection (Fig. 2A). Within 2 to $4 \mathrm{~h}$ post transfection some short tubular structures appeared in the protoplasts (Fig. 2B). Some long, tubular structures protruding from the surface of the protoplasts into the culture medium were observed $16 \mathrm{~h}$ after transfection (Fig. 2C). The MP-GFP expressed in the protoplasts showed heavy aggregates as foci in plasma membranes and tubules seemed formed from these foci (Fig. 2C). The tubule formation time and the tubule length varied with individual protoplasts examined, which may be due to the time required for MP-GFP gene expression and the amount of the MP-GFP expressed in the individual protoplasts, respectively. The length of these tubular structures could extend up to 60 $\mu \mathrm{m}$ (Fig. 2D). In addition, some mobile, bright punctate structures at the cortical cytoplasm were observable within 3 days post transfection (data not shown). Interestingly, we noted that the accumulation of MP-GFP fusion reached its peak at 40 to $48 \mathrm{~h}$ post transfection, after which the intensity of fluorescence decreased. The tubular structures were no longer discerned 3 to 4 days post transfection, which suggests 
that the tubule formation in the protoplasts is only transient. The disappearance of the MP-GFP fusion may be due to either exportation or degradation of the MP-GFP.

As a control, the protoplasts were transfected with pE6113GFP, which expressed only free GFP. Only a nonlocalized GFP distribution was observed in the transfected protoplasts (Fig. 2E). In contrast to the disappearance of the MP-GFP from the transfected protoplasts, the free GFP could be detected as long as the transfected protoplasts remained viable, up to 12 days after transfection (data not shown). These results suggest that the AlMV MP, but not GFP, has the capability to guide the fusion protein to localize as well as to aggregate at certain sites on the plasma membrane. From these sites the AlMV MP may subsequently mediate the tubule formation, which then contains the MP-GFP.

To determine if particular domains of AlMV MP are involved in the specific steps in tubule formation, we constructed four deletion fusion mutants of the AlMV MP gene. The first is an N-terminal deletion mutant pE6113-MP $\Delta 1$ 12GFP, which had the sequences encoding amino acids 1 to 12 of the MP gene deleted. Deletion of this region has been shown to have no effect on the association of the MP to cell wall (Erny et al. 1992; Berna 1995). This deletion construct was made by digesting the MP gene with $\mathrm{XhoI}$ and $\mathrm{KpnI}$ to release the DNA fragment MP $\Delta 1-12$ (Fig. 3A) and then ligating this fragment into pE6113-GFP XhoI and KpnI sites to produce pE6113-MP $\Delta 1-12 \mathrm{GFP}$. The mutant MP-GFP fusion should start at amino acid 13 (methionine) of AlMV MP. The protoplasts transfected with pE6113-MP $\Delta 1-12 \mathrm{GFP}$ produced tubular structures similar to those induced by the wild-type MP-GFP (data not shown).

The second deletion construct is pE6113-MPA1-77GFP, which had the sequences encoding amino acids 1 to 77 of the MP gene deleted. This region has been shown to be involved in the MP-cell wall association and protein-protein interaction (Erny et al. 1992; Berna 1995). It has been also shown that the predicted $\alpha$-helix motif between amino acids 23 and 36 is involved in the cell wall localization, possibly through the interaction with the membrane and cellular proteins (Berna 1995). A domain in AlMV MP within amino acids 36 to 81 is necessary for RNA binding (Schoumacher et al. 1994). Moreover, according to the hydrophilicity analysis (Kyte and Doolittle 1982), the amino acids 50 to 67 of AlMV MP are highly hydrophobic. This feature may allow the MP to transverse the ER membrane and route to its destination via the ER-Golgi protein transportation pathway (Engelman et al. 1986). To delete amino acids 1 to 77 from the AlMV MP, the cDNA fragment coding for amino acids of the MP 78-300 was PCR amplified with primer MPDN5 (5'GCTCTAGATGCTTCCTAAGATTGGACAGAG $\left.3^{\prime}\right)$ and primer MP3. The DNA fragment MP $\Delta 1-77$ (Fig. 3A) begins at the MP coding sequence for the amino acid 78 (methionine) and ends at the $3^{\prime}$ end of the MP gene. The primer MPDN5 contains an XbaI site (underlined) followed by the oligonucleotides that correspond to the AlMV MP coding sequences starting from amino acid 78. The amplified fragments of MP 78-300 gene were digested with $\mathrm{XbaI}$ and $\mathrm{KpnI}$, and then ligated into $X b a \mathrm{I}$ and $K p n \mathrm{I}$ sites on the digested pE6113MPGFP to produce the deletion mutant pE6113-MP 1 1-77GFP. In the protoplasts transfected with pE6113-MP $\Delta 1-77 \mathrm{GFP}$, the mutant MP-GFP showed uniform fluorescence distribution in the protoplasts (Fig. 3B). This result suggests that the $\mathrm{N}$ - terminal 13 to 77 amino acids of AlMV MP may be essential for either tubule formation or proper folding of the MP. The nonlocalized distribution shows that this mutant MP-GFP may not be able to interact with the plasma membrane or with other subcellular structures.

The third mutant construct, pE6113-MP $\Delta 84-142 \mathrm{GFP}$, had sequences encoding amino acids 84 to 142 deleted in the middle section of the MP, which is a domain with high surface probability (Emini et al. 1985). To delete amino acids 84 to 142 in the AlMV MP, two DNA fragments of MP1-83 and MP143-300 (Fig. 3A) were amplified by two PCR procedures with two pairs of the primers. For making the DNA fragment MP1-83, primer MP5 and the primer MPDMN3 (5'CG GGATCCAATCTTAGGAAGCATACGATTC 3') were used for the amplification of the $\mathrm{N}$ terminus of the MP gene coding for amino acids from 1 to 83. The primer MPDMN3 contains a BamHI site (underlined) followed by 22 oligonucleotides that are complementary to the AlMV MP coding sequences starting from amino acid number 83 to the $\mathrm{N}$ terminus of the AlMV MP gene. For making the DNA fragment MP143-300, the primer MPDMN5 (5'CGGGATCCATTCTGGCGAAA GATGCAGCGA 3') and the primer MP3 were used to amply the $\mathrm{C}$ terminus of the MP gene coding sequences for the amino acids from number 143 to the $\mathrm{C}$ terminus of the MP. The primer MPDMN5 contains a BamHI site (underlined) followed by 22 oligonucleotides that correspond to the AlMV MP coding sequences starting from amino acid number 143 . The two amplified DNA fragments, MP1-83 and MP143-300,

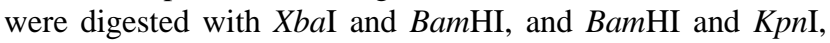
respectively. The two digested fragments were excised and then ligated into pE6113-MPGFP to generate the deletion construct pE6113-MP $\Delta 84-142 \mathrm{GFP}$. In the protoplasts transfected with pE6113-MP $\Delta 84-142$ GFP only a few, mobile, bright, punctate structures were observed in the cortical cytoplasm (Fig. 3C), suggesting this mutant was unable to aggregate at specific sites on plasma membranes.

The $\mathrm{C}$ terminus of the AlMV MP has been shown to be very important for the virus cell-to-cell movement, since deletion of 3 amino acids from this region abolished the infectivity of AlMV in plants (van der Vossen et al. 1995). To delete amino acids 226 to 300 from the AlMV MP, the fragment of the mutant MP1-225 was PCR amplified with the primer MP5 and the primer MPDC3 (5'GGGGTACCTAACCTTGTCCTATC AAGAACA $3^{\prime}$ ). The primer MPDC3 contains a KpnI site (underlined) followed by 22 oligonucleotides that are complementary to the coding sequences starting at amino acid number 225 from the $\mathrm{N}$ terminus. The amplified fragment MP $\Delta 226-300$ (Fig. 3A) was digested with $X b a \mathrm{I}$ and $K p n \mathrm{I}$ and then ligated into $X b a \mathrm{I}$ and $K p n \mathrm{I}$ linearized pE6113-GFP to generate the deletion construct, pE6113-MP $\Delta 226-300 \mathrm{GFP}$. In the protoplasts transfected with pE6113-MP $\Delta 226-300 \mathrm{GFP}$, which had the C-terminal region of the MP coding sequences deleted, some punctate structures were observed in the plasma membrane and cytoplasm (Fig. 3D), suggesting the C-terminal region is not essential for MP intracellular transport and affinity to plasma membranes but that it may have a role in tubule initiation and elongation.

In conclusion, our results showed that no other virus gene products except the MP are required to induce the tubular structures in the plant cells. In addition, the transient AlMVMP guided tubule formation in transfected tobacco protoplasts 

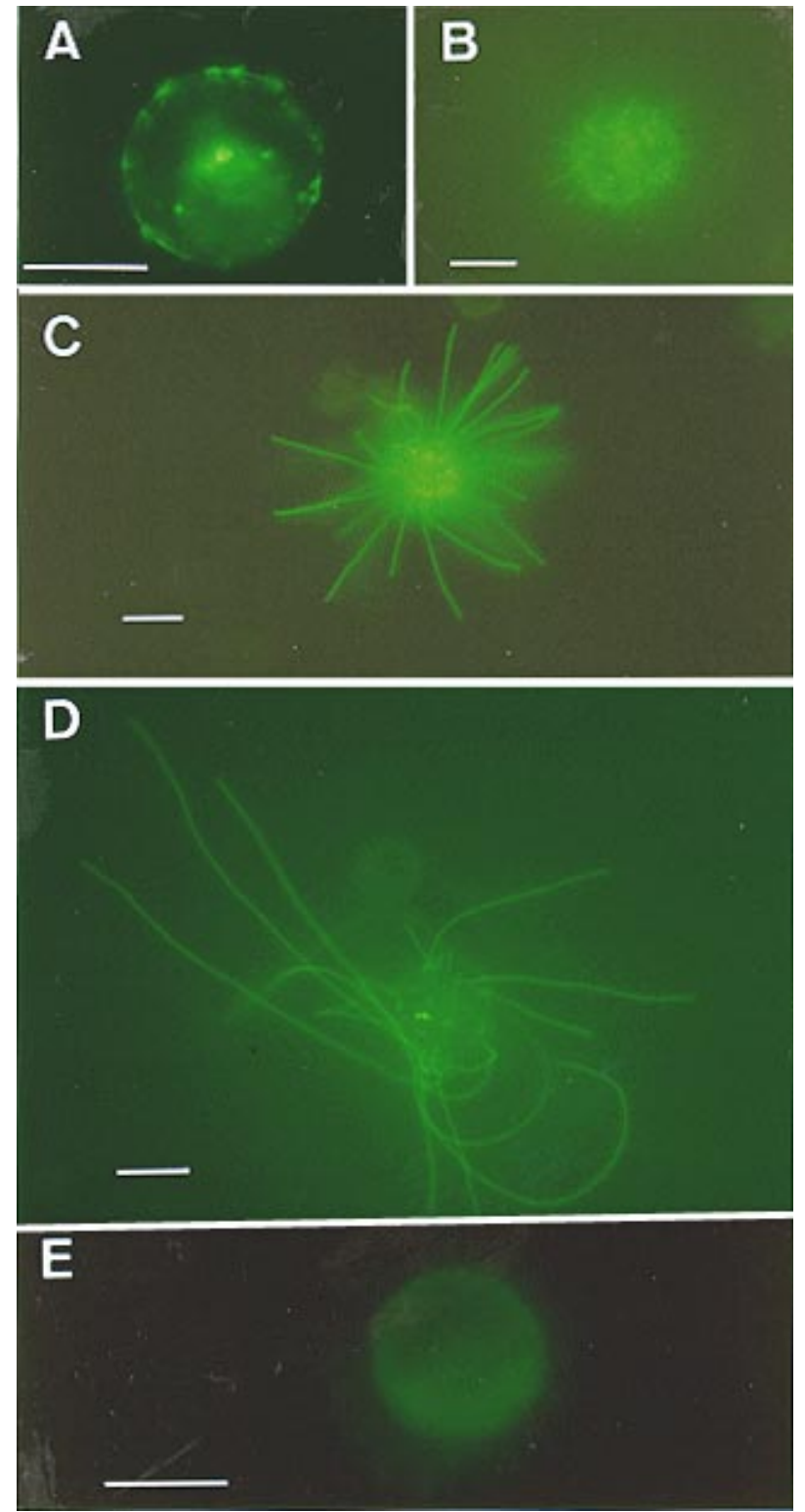

Fig. 2. Epifluorescence micrographs of tobacco BY-2 protoplasts expressing the movement protein-green fluorescence protein (MP-GFP) fusion or GFP only. The protoplast transfect with pE6113-MPGFP, producing MP-GFP, was observed by epifluorescence microscopy at (A) 2, (B) 4, (C) 16, and (D) 24 h post transfection. E, Protoplast transfected with pE6113-GFP, producing free GFP. Bars $=10 \mu \mathrm{m}$ in all photos.

found in this study suggests that AlMV may move from cell to cell via tubules.

\section{ACKNOWLEDGMENTS}

We wish to thank Nam-Hai Chua for the plasmid pGFP2, Masashi Ugaki for plasmid pE6113-GUS, and Shou-Wei Ding and Sek-Man Wong for helpful discussion. This work was supported by a grant from the National Science and Technology Board of Singapore.

\section{LITERATURE CITED}

Atabekov, J. G., and Taliansky, M. E. 1990. Expression of a plant virusencoded transport function by different viral genomes. Adv. Virus

\section{A}

$\begin{array}{llllllllllllllll}0 & 20 & 40 & 6,0 & 80 & 100 & 129 & 140 & 160 & 180 & 290 & 2230 & 240 & 260 & 280 & 390\end{array}$

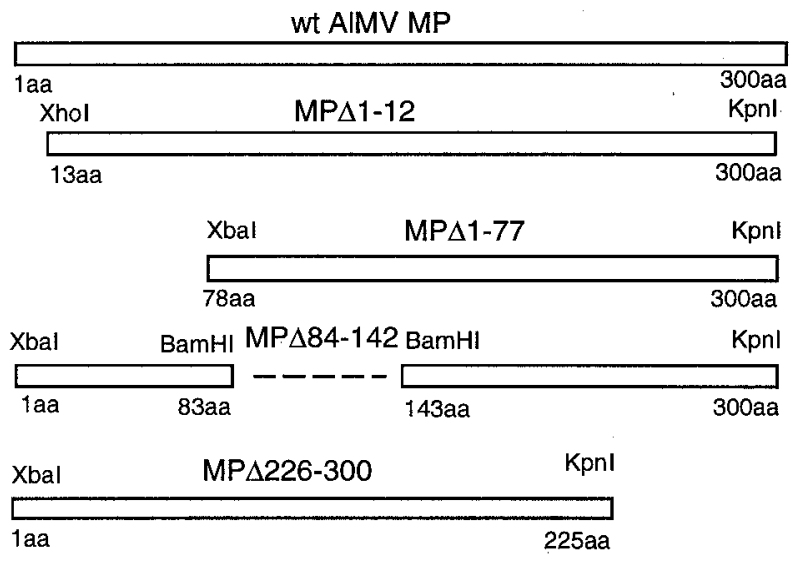

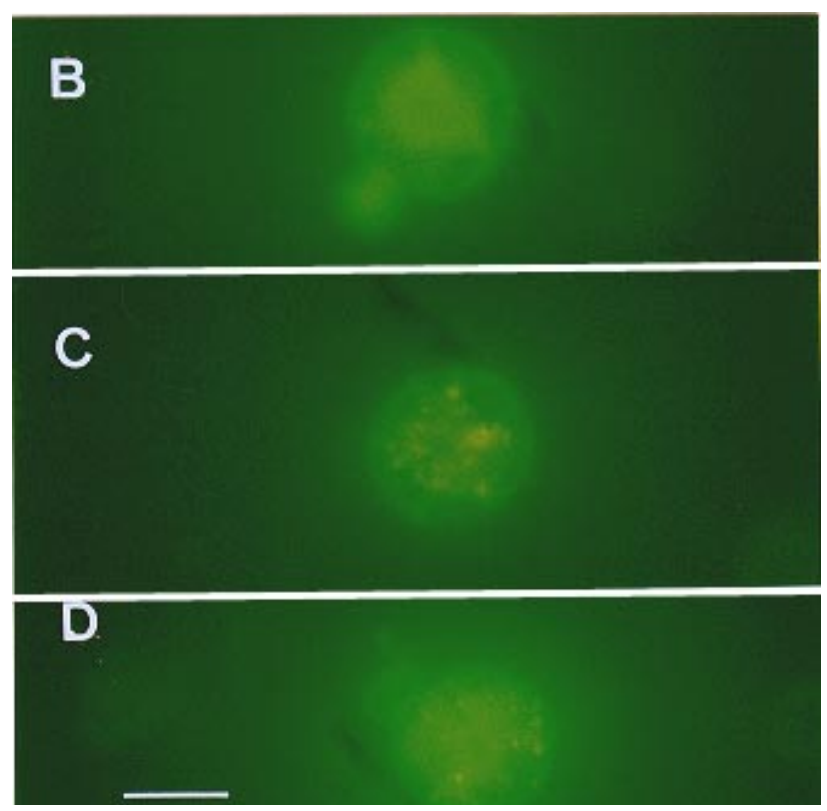

Fig. 3. Schematic illustration of the movement protein (MP) deletion mutants and epifluorescence micrographs of tobacco BY-2 protoplasts expressing the MP-green fluorescence protein (GFP) deletion mutants. The wild-type (wt) AlMV MP has 300 amino acids. A, Four MP deletion mutants were made as indicated in the open boxes. The protoplasts expressing the deletion mutant MP-GFPs were observed by epifluorescence microscopy for deletion of (B) N-terminal amino acids 1 to 77, (C) middle section amino acids 84 to 142 , and (D) C-terminal amino acids 226 to 300 . Bar $=10 \mu \mathrm{m}$.

Res. 38:201-248.

Banjoko, A., and Trelease, R. N. 1995. Development and application of an in vivo plant peroxisome import system. Plant Physiol. 107:10211028.

Berna, A. 1995. Involvement of residues within putative $\alpha$ helix motifs in the behavior of the alfalfa and tobacco mosaic virus movement proteins. Phytopathology 85:1441-1448

Chalfie, M., Tu, Y., Euskirchen, G., Ward, W. W., and Prasher, D. C. 1994. Green fluorescent protein as a marker for gene expression. Science 263:802-805.

Citovsky, V., Knorr, D., Schuster, G., and Zambryski, P. 1990. The P30 movement protein of tobacco mosaic virus is a single-stranded nucleic 
acid binding protein. Cell 4:637-647.

Citovsky, V., Wong, M. L., Shaw, A. L., Prasad, B. V. V., and Zambryski, P. 1992. Visualization and characterization of tobacco mosaic virus movement protein binding to single-stranded nucleic acids. Plant Cell 4:397-411.

Deom, C. M., Lapidot, M., and Beachy, R. N. 1992. Plant virus movement proteins. Cell 69:221-224.

Ding, B., Haudenshield, J. S., Hull, R. J., Wolf, S., Beachy, R. N., and Lucas, W. J. 1992. Secondary plasmodesmata are specific sites of localization of the tobacco mosaic virus movement protein in transgenic tobacco plants. Plant Cell 4:915-928.

Dore, J.-M., Van Dun, C. M. P., Pinck, L., and Bol, J. F. 1991. Alfalfa mosaic virus RNA3 mutants do not replicate in transgenic plants expressing RNA3-specific genes. J. Gen. Virol. 72:253-258.

Emini, E. A., Hughes, J. V., Permow. D. C., and Boger, J. 1985. Induction of hepatitis A virus-neutralizing antibody by a virus-specific synthetic peptide. J. Gen. Virol. 55:836-839.

Engelman, D. E., Steitz, T. A., and Goldman, A. 1986. Identifying nonpolar transbilayer helices in amino acid and sequences of membrane patterns. Annu. Rev. Biophys. Biophys. Chem. 15:321-353.

Erny, C., Schoumacher, F., Jung C., Gagey, M. J., Godefroy-Colburn, T. Stussi-Garaud, C., and Berna, A. 1992. An N-proximal sequence of the alfalfa mosaic virus movement protein is necessary for association with cell walls in transgenic plants. J. Gen. Virol. 73:2115-2119.

Godefroy-Colburn, T., Gagey, M.-J., Berna, A., and Stussi-Garaud, C. 1986. A non-structural protein of alfalfa mosaic virus in the walls of infected tobacco cells. J. Gen. Virol. 67:2233-2239.

Haseloff, J., and Amos, B. 1995. GFP in plants. Trends Genet. 11:328329.

Haseloff, J., Siemering, K. R., Prasher, D. C., and Hodge, S. 1997. Removal of a cryptic intron and subcellular localization of green fluorescent protein are required to mark transgenic Arabidopsis plants brightly. Proc. Natl. Acad. Sci. USA 94:2122-2127.

Heinlein, M., Epel, B. L., Padgett, H. S., and Beachy, R. N. 1995. Interaction of tobamovirus movement proteins with the plant cytoskeleton. Science 270:1983-1985.

Hull, R. 1991. The movement of viruses within plants. Sem. Virol. 2: 89-95.

Kasteel, D. T. J., Perbal, M.-C., Boyer, J.-C., Wellink, J., Goldbach, R. W., Maule, A. J., and van Lent, J. W. M. 1996. The movement protein of cowpea mosaic virus and cauliflower mosaic virus induce tubular structures in plant and insect cells. J. Gen. Virol. 77:2857-2864.

Kim, K.-S., and Lee, K.-W. 1992. Geminivirus-induced macrotubules and their suggested role in cell-to-cell movement. Phytopathology 82:664-669.

Koonin, E. V., Mushegian, A. R., Ryabov, E. V., and Dolja, V. V. 1991. Diverse groups of plant RNA and DNA viruses share related movement protein that may possess chaperone-like activity. J. Gen. Virol. 72:2895-2903.

Kyte, J., and Doolittle, R. F. 1982. A single method for display the hydropathic character of a protein. J. Mol. Biol. 157:105-132.

Lucas, W. J., and Gilbertson, R. L. 1994. Plasmodesmata in relation to viral movement within leaf tissues. Annu. Rev. Phytopathol. 32:387411.

Maule, A. J. 1991. Virus movement in infected plants. Crit. Rev. Plant Sci. 9:457-473.

McLean, B. G., Zupan, J., and Zambryski, P. C. 1995. Tobacco mosaic virus movement protein associates with the cytoskeleton in tobacco cells. Plant Cell 7:2101-2114.

Melcher, U. 1990. Similarities between putative transport protein of plant viruses. J. Gen. Virol. 71:1009-1018.

Mitsuhara, I., Ugaki, M., Hirochika, H., Ohshima, M., Murakami, T., Gotoh, Y., Katayose, Y., Nakamura, S., Honkura, R., Nishimiya, S., Ueno, K., Mochizuki, A., Tanimot, H., Tsugawa, H., Otsuki, Y., and Ohashi, Y. 1996. Efficient promoter cassettes for enhanced expression of foreign genes in dicotyledonous and monocotyledonous plants. Plant Cell Physiol. 37:49-59.

Morgan, M. K., and Ow, D. W. 1995. Polyethylene glycol-mediated transformation of tobacco leaf mesophyll protoplasts: An experiment in the study of Cre-lox recombination. Pages 1-16 in: Methods in Plant Molecular Biology: A Laboratory Course Manual. P. Maliga, D. Klessig, A. R. Cashmore, W. Gruissem, and J. E. Varner, eds. Cold Spring Harbor Laboratory, Cold Spring Harbor, NY.

Mushegian, A. R., and Koonin, E. V. 1993. Cell-to-cell movement of plant viruses: Insights from amino acid sequence comparisons of movement proteins and from analogies with cellular transport systems. Arch. Virol. 133:239-257.

Nassuth, A., and Bol, J. F. 1983. Altered balance of the synthesis of plus- and minus-strand RNAs induced by RNAs 1 and 2 of alfalfa mosaic virus in the absence of RNA 3. Virology 124:75-85.

Oparka, K. J., Boevink, P., and Santa-Cruz, S. 1996. Studying the movement of plant viruses using green fluorescent protein. Trends Plant Sci. 1:412-418.

Perbal, M.-C., Thomas, C. L., and Maule, A. J. 1993. Cauliflower mosaic virus gene I product (P1) forms tubular structures which extend from the surface of infected protoplasts. Virology 195:281-285.

Poirson, A., Tuner, A. P., Giovane, C., Berna, A., Roberts, K., and Godefroy-Colburn, T. 1993. Effect of the alfalfa mosaic virus movement protein expressed in transgenic plants on the permeability of plasmodesmata. J. Gen. Virol. 74:2459-2561.

Ritzenthaler, C., Schmit, A.-C., Michler, P., Stussi-Garaud, C., and Pinck, L. 1995. Grapevine fanleaf nepovirus P38 putative movement protein is located on tubules in vivo. Mol. Plant-Microbe Interact. 8:379-387.

Robards, A. W., and Lucas, W. J. 1990. Plasmodesmata. Annu. Rev. Plant Physiol. Plant Mol. Biol. 41:369-419.

Schoumacher, F., Erny, C., Berna, A., Godefroy-Colburn, T., and StussiGaraud, C. 1992a. Nucleic-acid-binding properties of the alfalfa mosaic virus movement protein produced in yeast. Virology 188:896899

Schoumacher, F., Gagey, M.-J., Maira, M., Stussi-Garaud, C., and Godefroy-Colburn, T. 1992b. Binding of RNA by the alfalfa mosaic virus movement protein is biphasic. FEBS Lett. 308:231-234.

Schoumacher, F., Giovane, C., Maira, M., Poirson, A., GodefroyColburn, T., and Berna, A. 1994. Mapping of the RNA-Binding domain of the alfalfa mosaic virus movement protein. J. Gen. Virol. 75: 3199-3202.

Sheen, J., Hwang, S., Niwa, Y, Kobayashi, H., and Galbraith, D. W. 1995. Green-fluorescent protein as a new marker in plant cells. Plant J. 8:777-784.

Storms, M. M. H., Kormelink, R., Peters, D., van Lent, J. W. M., and Goldbach, R. W. 1995. The nonstructural NSm protein of tomato spotted wilt virus induces tubular structures in plant and insect cells. Virology 214:485-493.

Stussi-Garaud, C., Garaud, J.-C., Berna, A., and Godefroy-Colburn, T. 1987. In situ location of an alfalfa mosaic virus nonstructural protein in plant cell walls: Correlation with virus transport. J. Gen. Virol. 68: 1179-1184.

Thomas, C. L., and Maule, A. J. 1995. Identification of structural domains within the cauliflower mosaic virus movement protein by scanning deletion mutagenesis and epitope tagging. Plant Cell 7:561-572.

van der Kuyl, A. C., Neeleman, L., and Bol, J. 1991. Deletion analysis of cis- and trans- acting elements involved in replication of alfalfa mosaic virus RNA3 in vivo. Virology 183:687-694.

van der Vossen, E. A. G., Notenboom, T., and Bol, J. F. 1995. Characterization of sequences controlling the synthesis of alfalfa mosaic virus subgenomic RNA in vivo. Virology 212:663-672.

van Lent, J. W. M., Wellink, J., and Goldbach, R. 1990. Evidence for the involvement of the $58-\mathrm{kDa}$ and $48-\mathrm{kDa}$ proteins in the intercellular movement of cowpea mosaic virus. J. Gen. Virol. 71:219-223.

Waigmann, E., Lucas, W. J., Citovsky, V., and Zambryski, P. 1994. Direct functional assay for tobacco mosaic virus cell to cell movement protein and identification of a domain involved in increasing plasmodesmal permeability. Proc. Natl. Acad. Sci. USA 91:1433-1437.

Ward, B. M., Medville, R., Lazarowitz, S. G., and Turgeon, R. 1997. The geminivirus BL1 movement protein is associated with endoplasmic reticulum-derived tubules in developing phloem cells. J. Virol. 71:3726-3733.

Wellink, J., and van Kammen, A. 1989. Cell-to-cell transport of cowpea mosaic virus requires both the $58 \mathrm{~K} / 48 \mathrm{~K}$ proteins and the capsid proteins. J. Gen. Virol. 69:751-755

Wellink, J., van Lent, J. W. M., Verver, J., Sijen, T., Goldbach, R. W., and van Kammen, A. B. 1993. The cowpea mosaic virus M-RNAencoded 48-kilo Dalton protein is responsible for induction of tubular structures in protoplasts. J. Virol. 67:3660-3664

Wolf, S., Deom, C. M., Beachy, R. N., and Lucas, W. J. 1989. Movement protein of tobacco mosaic virus modifies plasmodesmatal size exclusion limit. Science 246:377-379. 